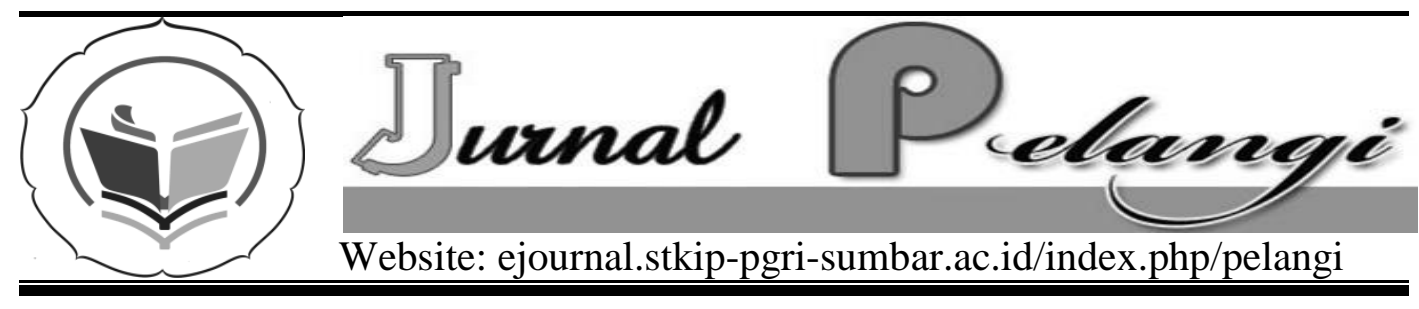

\title{
BIMBINGAN KELOMPOK SEBAGI ALTERNATIF UNTUK MENINGKATKAN KOMUNIKASI INTERPERSONAL SISWA
}

\author{
Rici Kardo \\ STKIP PGRI Sumatera Barat \\ ricikkardo@ymail.com
}

INFO ARTIKEL

Diterima :01-01-2014

Disetujui :01-12-2014

Kata Kunci:

Bimbingan kelompok

Komunikasi

interpersonal

Siswa

\begin{abstract}
Abstrak
Komunikasi interpersonal adalah sebuah proses sosial dimana masing-masing individu saling mempengaruhi satu sama lain. Fenomena yang terjadi pada hubungan siswa dengan komunikasi interpersonal menjadi salah paham ketika siswa mempunyai masalah dalam komunikasi. Kualitas pemahaman tidak menjadi masalah ketika siswa berinteraksi dengan siswa lain. Jasa konseling kelompok adalah jasa bimbingan dan konseling yang dapat digunakan untuk melatih komunikasi interpersonal siswa. Dengan melaksanakan jasa kelompok konseling, siswa akan diberi pemahaman dan pelatihan komunikasi interpersonal. Penelitian ini bertujuan untuk mengungkapkan keefektifan jasa kelompok konseling dalam meningkatkan komunikasi interpersonal siswa.
\end{abstract}

\section{Abstract}

Keywords:

Guidance Services

Group,

Communication

Interpersonal,

Students

\begin{tabular}{l} 
Abstract \\
\hline Interpersonal Communication is a social process by \\
which individuals are engaged in them influence each \\
other. The phenomenon that occurs in students \\
associated with interpersonal communication is a lot of \\
misunderstanding when students have problems \\
communicating, mutual understanding is often not the \\
case when students interact with other students. Group \\
counseling services are in guidance and counseling \\
services that can be used to improve students' \\
interpersonal communication. By conducting group \\
counseling services, students will be given the \\
understanding and practice of communication \\
interpsersonal. This study aims to reveal the \\
effectiveness of group counseling services in improving \\
\hline
\end{tabular}




\section{PENDAHULUAN}

Pendidikan merupakan sentral pembangunan agar tatanan dunia baru penuh rahmat dan kemajuan dapat diraih serta dapat mencapai perkembangan yang optimal untuk para peserta didik baik lahir maupun batin. Berdasarkan UU No. 20 tahun 2003 bab I pasal 1 tentang Sistem Pendidikan Nasional dirumuskan: Pendidikan adalah usaha sadar dan terencana untuk mewujudkan suasana belajar dan proses pembelajaran agar peserta didik secara aktif mengembangkan potensi dirinya untuk memiliki kekuatan spiritual keagamaan, pengendalian diri, kepribadian, kecerdasan, akhlak mulia, serta keterampilan yang diperlukan dirinya, masyarakat, bangsa dan negara.

Bertolak dari tujuan pendidikan nasional yang tercantum dalam UU RI nomor 20 tahun 2003 ini, sekolah merupakan salah satu lembaga pendidikan formal yang bertujuan mendewasakan siswa, sehingga mereka dapat mencapai perkembangan yang optimal. Wadah untuk mencapai tujuan tersebut adalah melalui proses pendidikan, khususnya di sekolah. Sekolah sebagai suatu lembaga pendidikan mempunyai tanggung jawab yang besar dalam mendidik dan menyiapkan para siswa agar siswa berhasil dalam proses pendidikan, sehingga para siswa mampu menghadapi tantangan-tantangan masa depan.

Bimbingan dan konseling memiliki peran yang sangat penting untuk dapat membantu terciptanya tujuan pendidikan itu sendiri. Konselor memiliki peran yang sangat penting dalam mengembangkan potensi-potensi siswa sehingga mampu memberdayakan segenap potensi pada dirinya untuk dapat menjadi pribadi yang bermanfaat. Selain itu pendidik juga memiliki kewajiban untuk membantu siswa ketika mengalami masalah-masalah dalam mengembangkan kemampuan yang dimilikinya.

Didalam pemberian layanan untuk meningkatkan kemandirian dan mengembangkan kemampuan siswa secara optimal. Salah satu layanan dalam bimbingan dan konseling yang merupakan layanan dasar yang harus dilaksanakan oleh seluruh konselor/guru BK yaitu layanan bimbingan kelompok. Bimbingan kelompok bertujuan memperoleh berbagai bahan yang bermanfaat dari nara sumber (terutama guru BK) untuk kehidupan sehari-hari siswa (Dewa Ketut Sukardi, 2003). Bahan-bahan itulah yang nantinya akan kita 
berdayaguna bagi siswa untuk dapat meningkatkan kehidupan efektif sehari-hari.

Menurut Havigurst (dalam Syamsu Yusuf 2011) sekolah mempunyai peranan atau tanggung jawab penting dalam membantu para siswa dalam mencapai tugas perkembanganya, dan sekolah seyogyanya berupaya menciptakan iklim yang kondusif atau kondisi yang memfasilitasi siswa dalam mencapai tugas perkembanganya yang menyangkut aspek-aspek kematangan dalam berinteraksi sosial, kematangan personal dalam mencapai filsafat hidup dan kematangan dalam beriman dan bertaqwa kepada Tuhan Yang Maha Esa. Untuk mencapai aspek perkembangan tersebut, maka siswa itu harus dapat menerima keadaan fisiknya dan memanfaatkanya secara efektif, mencapai kemandirian emosional, mengembangkan konsep dan keterampilan intelektual yang perlu bagi kompetensinya.

Bimbingan dan konseling merupakan upaya bantuan yang diberikan oleh guru pembimbing kepada siswa yang menggunakan prosedur, cara dan bahan agar individu mampu mandiri. Proses kemandirian individu tidak lepas dari adanya komunikasi dalam proses sosialisasi di lingkungan dimana individu tersebut berada. Komunikasi ini sangat berperan dalam pembentukan kepribadian individu, dengan komunikasi individu dapat melangsungkan hidupnya baik di lingkungan keluarga, sekolah maupun masyarakat. Di lingkungan sekolah siswa dituntut mampu berkomunikasi dengan baik dengan warga sekolah yakni guru, staf tata usaha, teman sebaya maupun personel sekolah lainnya. Siswa yang memiliki perilaku komunikasi antarpribadi yang baik akan mudah bersosialisasi dan lancar dalam memperoleh pemahaman dari guru dan sumber belajar di sekolah. Belajar bersosialisasi dan berkomunikasi dengan lingkungan sekitar merupakan proses tak henti-hentinya dalam kehidupan individu, siswa di Sekolah Menengah Atas memasuki tahap perkembangan remaja. Remaja adalah peralihan dari masa anak-anak ke masa remaja penuh ketergantungan menuju masa pembentukan tanggung jawab. Perubahan yang terjadi masa remaja akan mempengaruhi perilaku individu tergantung pada kemampuan dan kemauan individu pada masa remaja untuk mengungkapkan keprihatinan dan kecemasanya kepada orang lain, sehingga ia dapat memperoleh pandangan yang baru dan lebih baik.

Siswa merupakan individu yang memiliki karakteristik yang berbedabeda dalam proses perkembangannya memerlukan bantuan dalam mengadakan komunikasi interpersonal yang positif dilingkungan keluarga, sekolah dan masyarakat. Siswa yang kurang dapat berkomunikasi akan dapat 
menghambat pembentukan kepribadian dan aktualisasi diri dalam kehidupan terutama dalam meraih prestasi disekolah dan dikhawatirkan dapat menimbulkan masalah-masalah lain yang lebih kompleks. Reaksi efektif terhadap perubahan siswaterutama ditentukan oleh kemampuan berkomunikasi yakni cara untuk mengatasi kecemasan yang selalu disertai tekanan (Dumbar Hurlock, 1998)

Berdasarkan pengamatan di lapangan yang telah di rasakan saat ini masih terdapat siswa kurang mampu berkomunikasi dengan baik. Hal ini dilatarbelakangi kecenderungan saat ini siswa lebih banyak berinterksi sosial melalui jaringan dunia maya sehingga ketika dihadapkan dengan situasi sebenarnya dalam komunikasi secara langsung, terjadi ketidak saling pengertian satu sama lain. Akibatnya siswa banyak sekali mengalami permasalahan kesalah pahaman antar siswa dengan siswa ataupun siswa dengan guru.

Hal ini dikhawatirkan dapat menimbulkan permasalahan yang kompleks. siswa merupakan bagian dari masyarakat yang dituntut untuk dapat berkomunikasi dengan orang lain dilingkungan sekolah dan di luar sekolah dimana siswa hampir sebagian waktunya digunakan untuk berinteraksi di sekolah. Kebutuhan siswa dalam perlakuan sosialnya disebabkan siswa dituntut untuk berinteraksi dengan orang lain dalam situasi tertentu. Sehingga sekolah sebagai suatu lingkungan pendidikan harus dapat menerapkan, menciptakan dan memberikan suasana psikologis yang mendorong perilaku sosial, sehingga kebutuhan sosial yang diharapkan dapat terpenuhi.

Memperhatikan gambaran di atas, hal-hal yang perlu diperhatikan adalah: masih banyak terdapat siswa yang kurang mampu berkomunikasi interpersonalnya, dalam hal ini langkah menangani siswa yang di bahas di atas lebiah efektif layanan bimbingan kelompak adalah salah satu alternatif bisa menangani siswa yang terganggu dalam komunikasi interpersonal.

\section{METODA PENELITIAN}

Jenis penelitian ini adalah penelitian quasi experiment (eksperimen semu). Desian dalam penelitian ini menggunakan PretestPosttest Control Group Desian dalam penelitian ini terdapat dua kelompok, kemudian diberi pretest untuk mengetahui keadaan awal. Kemudian diberikan perlakuan pada kedua kelompok dengan perlakukan yang berbeda. Populasi dari penelitian ini adalah siswa SMA 2 Padang kelas XI yang terdaftar pada tahun ajaran 2012/2013, lalu memberikan instrumen komunikasi interpersonal secara keseluruhan kepada siswa kelas XI IPS 3 dan 4 yang terpilih menjadi sampel di SMA N 2 Padang. Setelah diketahui bahwa antara kedua 
kelompok penelitian setara, Menurut (Prayitno, 2012) tahap-tahap selanjutnya melaksanakan bimbingan kelompok adalah sebagai eksperimen, yaitu peneliti berikut:

memberikan perlakuan khusus berupa layanan bimbingan kelompok dengan materi komunikasi interpersonal kepada kelompok eksperimen dan layanan informasi pada kelompok kontrol. Pelaksanaan layanan informasi juga dengan materi terkait dengan komunikasi interpersonal. Pelaksanaan eksperimen akan dilakukan oleh peneliti sendiri.

Adapun topik pembahasan yang akan digunakan dalam layanan bimbingan kelompok yang bertujuan untuk dapat meningkatkan komunikasi interpersonal siswa, dengan pelaksanaan 10 kali pertemuan.

\section{HASIL DAN PEMBAHASAN}

Bimbingan kelompok berlangsung melalui lima tahap.

1) Tahap Pembentukan

Tahap ini merupakan tahap pengenalan, tahap melibatkan diri atau proses memasuki diri ke dalam kehidupan kelompok. Variasi dalam hal jenis kelamin, unsur pendidikan dan pengalaman menjadi pertimbangan dalam pembentukan kelompok. Pada tahap ini juga tempat duduk peserta kelompok diatur dengan membentuk sebuah lingkaran, sehingga setiap anggota kelompok dapat melihat satu sama lainnya secara langsung. Pola keseluruhan pada tahap ini, termasuk tema, tujuan, kegiatan dan peranan pemimpin kelompok, dapat digambarkan sebagai berikut : 


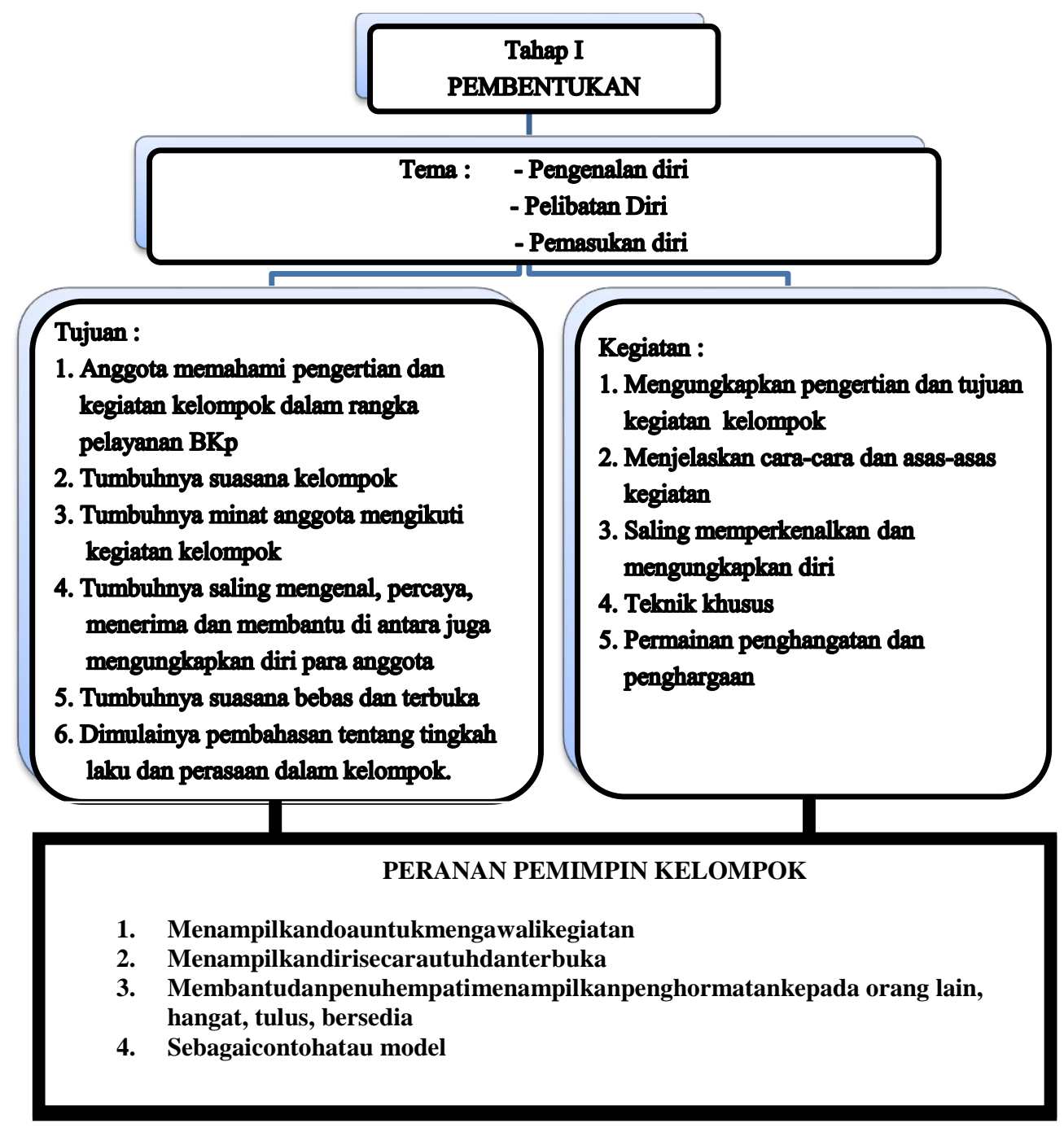

\section{Gambar ITahap Pembentukan}

2). Tahap Peralihan

Setelah suasana kelompok

terbentuk dan dinamika

kelompok sudah mulai tumbuh,

kegiatan kelompok hendaknya

dibawa lebih jauh oleh pemimpin

kelompok menuju kegiatan

kelompok sebenarnya.Untuk itu

perlu dilakukan tahap peralihan

sebelum melangkah lebih jauh ke tahap kegiatan.Pada tahap ini pemimpin kelompok menjelaskan peranan para anggota kelompok dalam kelompok.Kemudian pemimpin kelompok menawarkan apakah para anggota sudah siap memulai kegiatan.Tahap peralihan merupakan 
'jembatan' antara tahap pembentukan dan kegiatan.Adakalanya jembatan ditempuh dengan amat mudah dan lancar, artinya para anggota kelompok dapat memesuki tahap kegiatan dengan penuh kemauan dan kesukarelaan. Namun, adakalanya juga jembatan itu ditempuh dengan susah payah, artinya para anggota kelompok enggan memasuki tahap kegiatan yang merupakan tahap sebenarnya. Adapun pola tahap peralihan secara keseluruhan digambarkan ke dalam gambar 2 sebagai berikut.

3). Tahap Kegiatan

Tahap ini merupakan kehidupan yang sebenarnya dari kelompok. Namun kelangsungan kegiatan kelompok pada tahap ini amat tergantung pada hasil dari kedua tahap sebelumnya. Jika tahaptahap sebelumnya berhasil dengan baik, maka tahap ketiga itu kemungkinan besar akan berlangsung dengan lancar. Pada tahap ketiga ini ada topik tugas dan ada topik bebas. Topik bebas dikemukakan oleh anggota kelompok dan topik tugas ditentukan oleh pemimpin kelompok. Dalam penelitian ini akan digunakan satu topik saja, yaitu topik tugas. Seluruh peserta kelompok berperan aktif dan terbuka mengemukakan pikiran dan pendapatnya terkait topik yang dibahas dalam kelompok. Pada tahap ini, hubungan antar anggota kelompok tumbuh dengan baik dan pada tahap ini topik dibahas secara mendalam, luas dan tuntas. Sehingga wawasan, pengetahuan, dan nilai yang tertanam dalam diri tiap anggota 


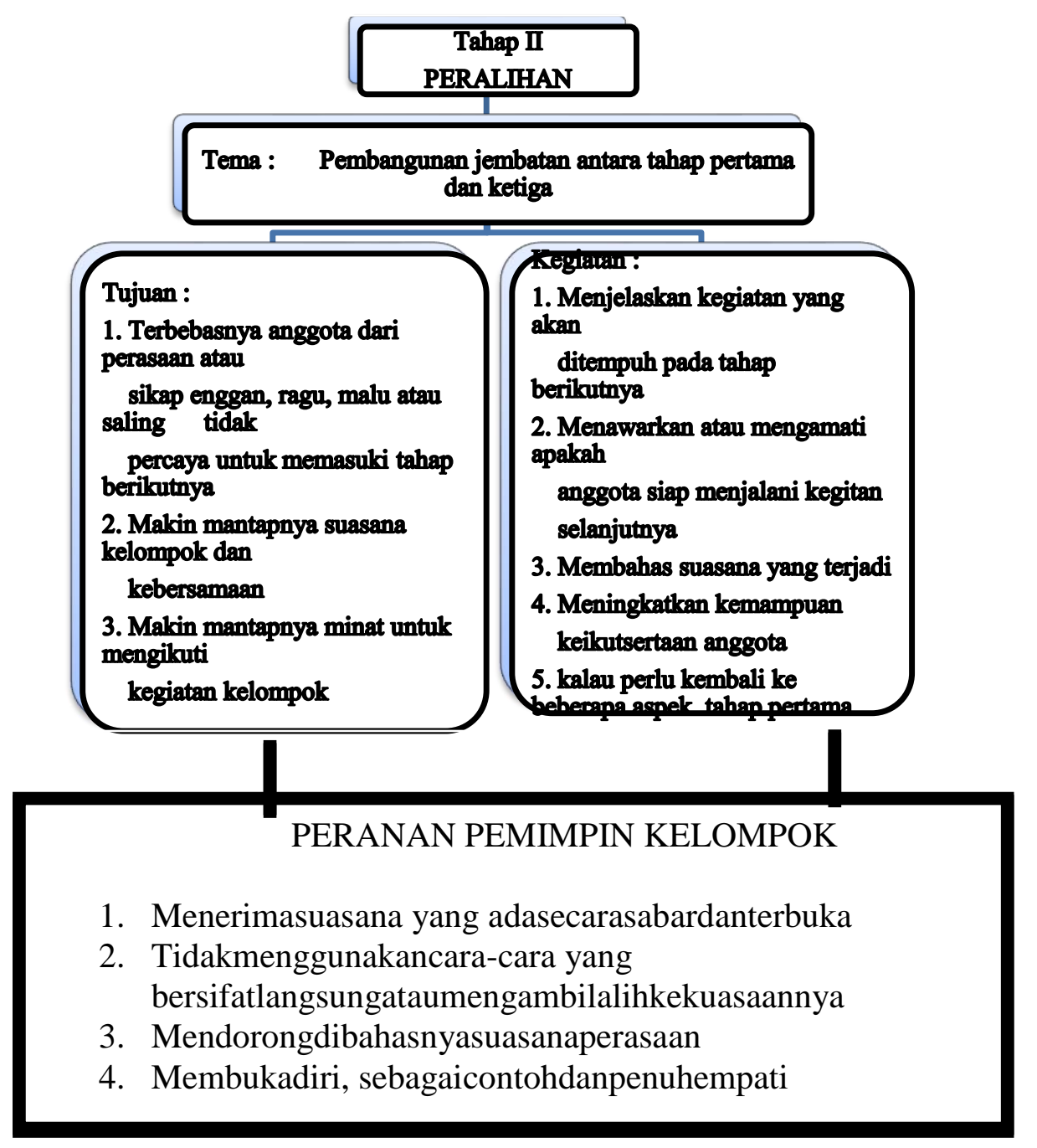

Gambar 2. Tahap Peralihan

kelompok semakin baik.Setiap yang didapat dari hasil bahasan dalam anggota kelompok dilatih berfikir bimbingan kelompok. Pola kritis, analisis, sistematis, dan logis, keseluruhan tahap ketiga, sehingga di dalam diri para anggota digambarkan secara keseluruhan kelompok tertanam tekad untuk dalam bagan di bawah ini : mengaplikasikan segala yang baik 


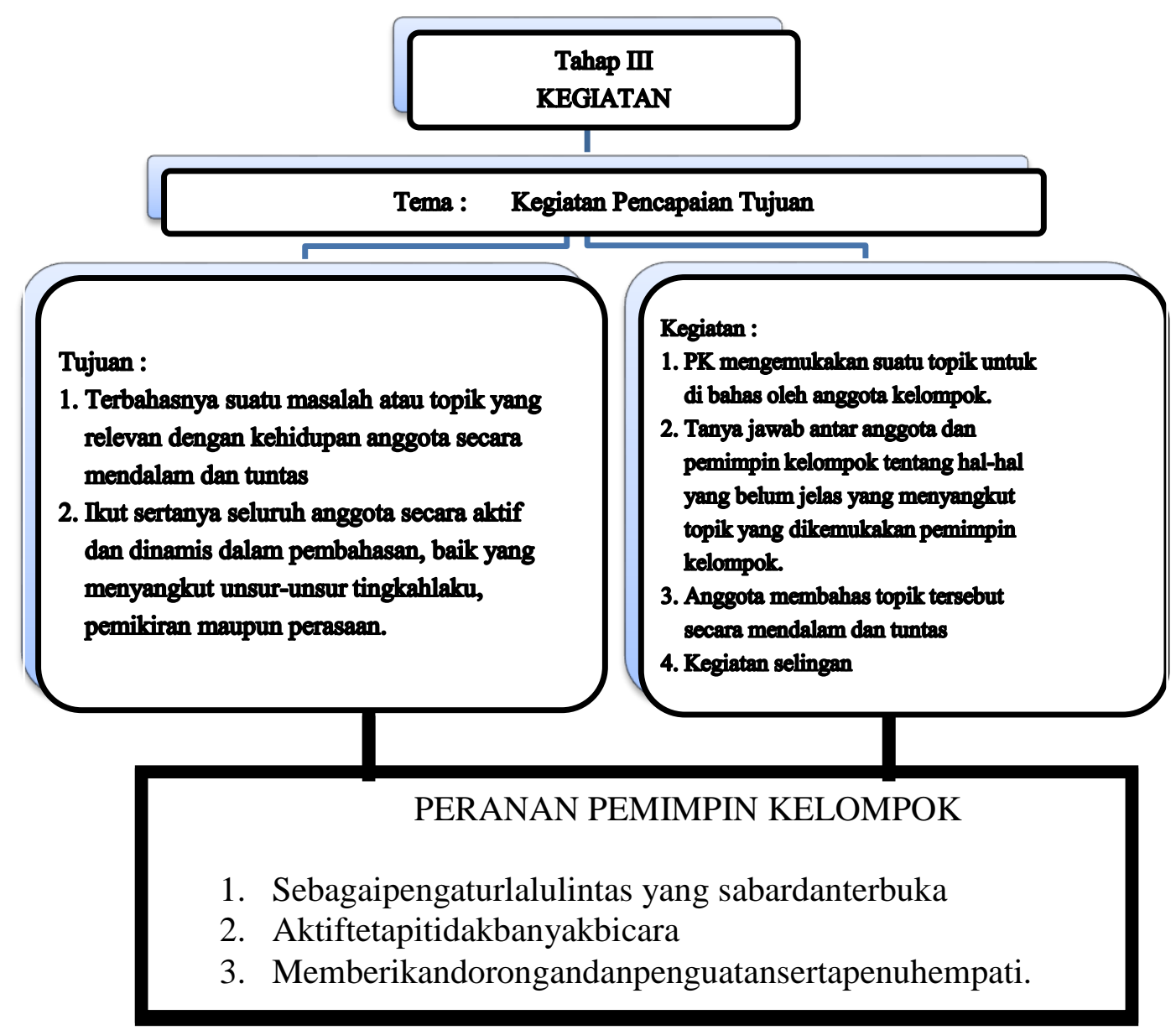

Gambar 3. Tahap Kegiatan

4) Tahap Penyimpulan

Tahap penyimpulan yaitu tahapan untuk melihat kembali apa yang sudah dilakukan dan dicapai oleh kelompok. Peserta kelompok diminta melakukan refleksi berkenaan dengan kegiatan pembahasan yang baru saja mereka ikuti.Pola keseluruhan tahap ke empat, dapat digambarkan sebagai berikut : 


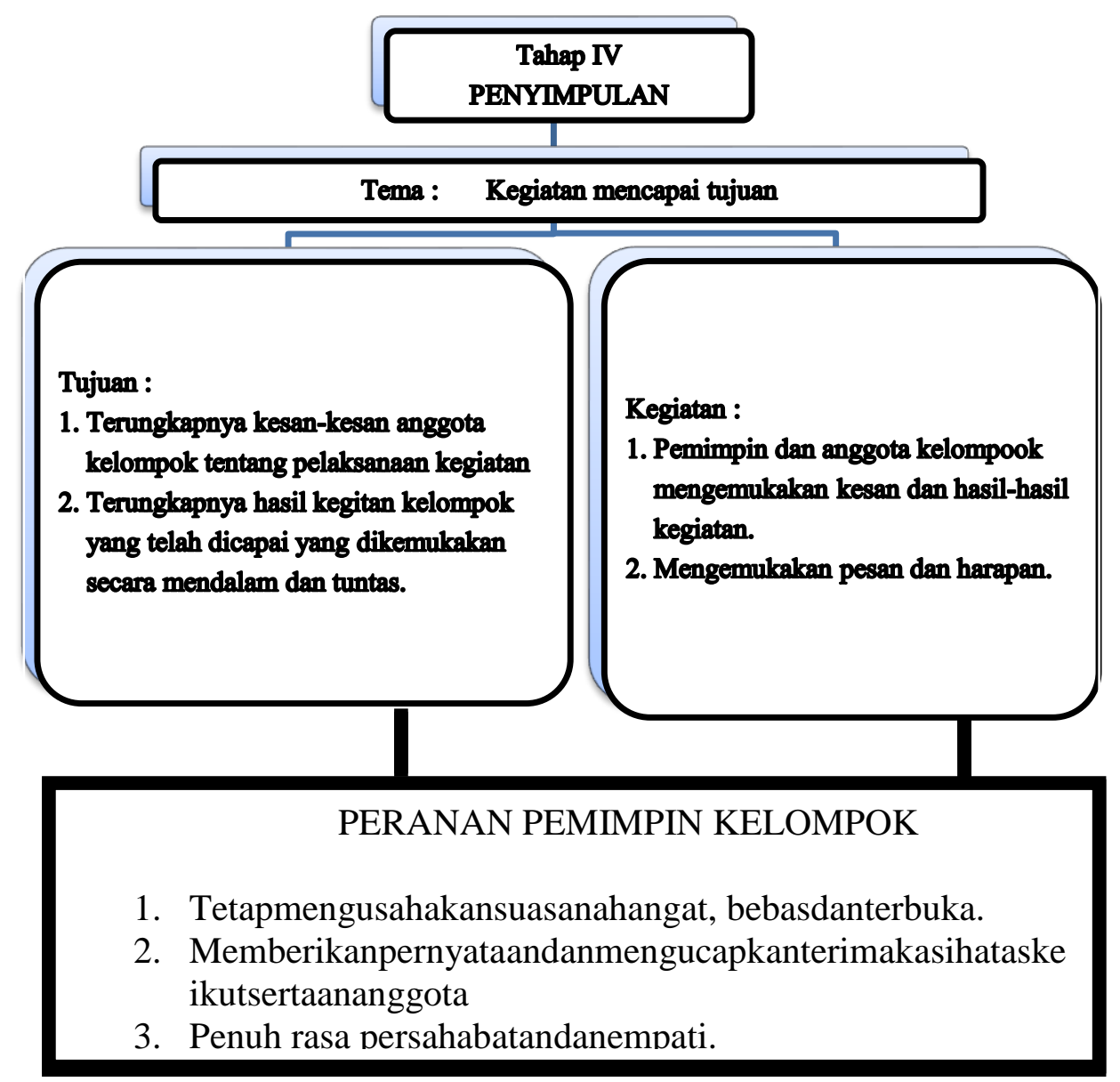

Gambar 4. Tahap Penyimpulan

\section{5). Tahap Pengakhiran}

Tahap pengakhiran ini adalah tahap yang harus terjadi pada saat yang dianggap tepat.Pada tahap ini dibahas terkait frekuensi pertemuan kelompok dan juga pembahasan keberhasilan kelompok. Dalam pembahasan frekuensi pertemuan, hendaknya dibahas tentang kapan dan berapa kali pertemuan akan dilakukan. Sedangkan pada pembahasan keberhasilan kelompok, hendaknya terfokus pada komitmen anggota kelompok. Seperti yang dikemukakan oleh Prayitno (1995), bahwa:"Ketika kelompok memasuki tahap pengakhiran, kegiatan kelompok hendaknya berpusat pada pembahasan dan penjelajahan tetang apakah anggota kelompok mampu menerapkan hal-hal yang telah dipelajari dalam kehidupan mereka sehari-hari". Pola keseluruhan tahap ke empat, dapat digambarkan sebagai berikut : 


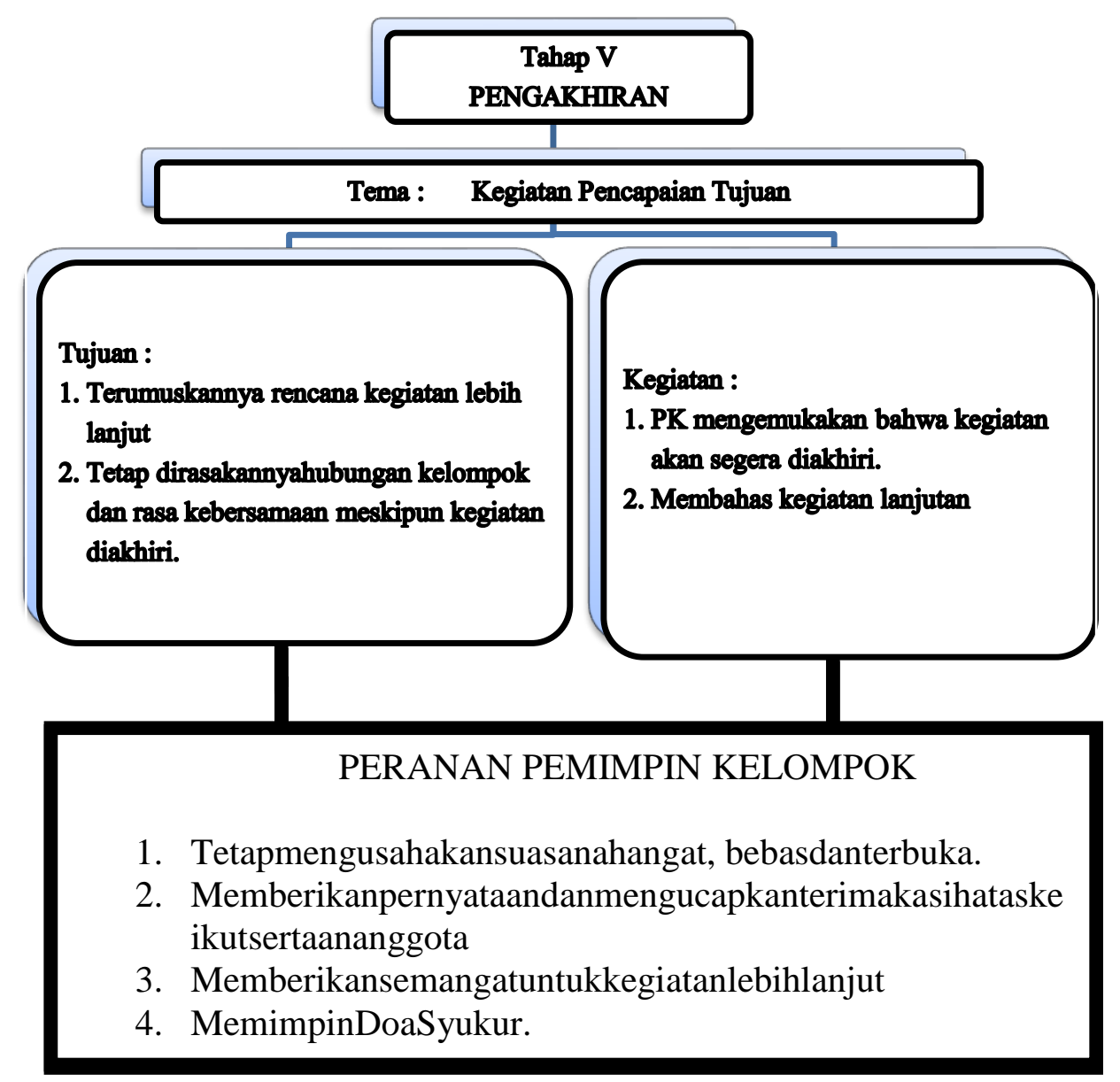

Gambar 5. Tahap Pengakhiran

KESIMPULAN DAN SARAN

Berdasarkan hasil penelitian dapat ditarik kesimpulan, yang merupakan ringkasan jawaban atas fokus penelitian sebagai berikut:

1. Kondisi siswa sebagian mengalami berbagai

permasalahan yang terungkap melalui opservasi dan wawancara. Sebagian besar mengalami masalah dalam komuniasi interpersonal.

2. Pelayanan konseling khususnya layanan bimbingan kelompok dan layanan informasi, bagi siswa dapat dilaksanakan untuk $\begin{array}{lrr}\text { membantu siswa dalam } & \text { dengalah } \\ \text { pengentasan masalah } & \text { mereka } \\ \text { serta dirasakan } & \text { sangat }\end{array}$ bermanfaat. Kedua jenis layanan konseling ini dapat mengembalikan kehidupan efektif sehari-hari mereka.

Berdasarkan hasil-hasil penelitian, pembahasan, dan kesimpulan yang telah dikemukakan, ada beberapa saran yang dapat diajukan sebagai tindak lanjut penelitian ini, yaitu sebagai berikut :

1. Bagi Guru Bimbingan dan Konseling 
a. Meningkatkan kemampuan menyelenggarakan layanan bimbingan kelompok, membuat variasi dalam penggunaan teknik penyelenggaraan layanan bimbingan kelompok, dan menggunakan media yang dapat meningkatkan keberhasilan layanan bimbingan kelompok

b. Meningkatkan kerjasama dengan mata pelajaran untuk mengidentifikasi masalah siswa yang nampak dalam proses pembelajaran terkait dengan komunikasi interpersonal. Melalui kerjasama yang efektif, guru BK akan dapat secara tepat menentukan materi layanan bimbingan kelompok kepada siswa.

2. Bagi Peserta Didik

Berpartisipasi dan berperan aktif dalam penyelenggaraan layanan bimbingan kelompok yang diselenggarakan oleh siswa. Selain itu keterbukaan peserta didik akan masalah yang dialaminya akan semakin membantu guru BK dalam menentukan solusi yang akan diberikan untuk membantu mengatasi masalah siswa.

3. Bagi Peneliti lainnya

Perlu dilakukan penelitian yang serupa dengan mempelajari kelemahan-kelemahan dalam penelitian ini, ataupun dengan mengembangkan penelitian ini dengan dilatarbelakangi oleh konteks yang berbeda agar dapat membandingkan temuan dari hasil penelitian ini.

4. Guru Bidang Studi

Membangun kerjasama antara guru pembimbing dengan guru bidang studi sangatlah penting, hal ini merupakan upaya pencegahan kesulitan belajar anak terhadap bidang studi tertentu, terutama yang berkaitan permasalahan komunikasi interpersonal siswa yang dapat menggangu aktifitas sekolah siswa.

5. Kepala Sekolah

Sebagai pengambil kebijakan, kepala sekolah hendaknya memberikan kesempatan pada guru bimbingan dan konseling untuk aktif mengikuti pelatihanpelatihan yang bermanfaat dalam meningkatkan kemampuan menyelenggarakan bimbingan kelompok. Selain itu, kepala sekolah dapat meningkatkan fasilitas ruang $\mathrm{BK}$, terutama ruangan untuk menyelenggarakan layanan bimbingan kelompok.

\section{UCAPAN TERIMAKASIH}

Terbitnya tulisan ini tidak terlepas dari bantuan berbagai pihak, untuk itu penulis ucapkan terima kasih yang sebesar-basarnya kepada Pihak STKIP PGRI Sumatera Barat khususnya pengelola jurnal Pelangi yang telah memberikan kesempatan 
kepada penulis untuk menulis dijurnal Pelangi. Selanjutnya penulis juga berterima kasih kepada para penyumbang sumber insirasi yang telah memerikan inspirasi bagi penulis untuk mengutip atau menggunakan tulisannya sebagai bahan referensi.

\section{DAFTAR PUSTAKA}

A. Muri Yusuf.1996. Teknik Analisa Data. Padang: FIP UNP

2009. Metodologi Penelitian. Dasar-dasar Penyelidikan Ilmiah. Padang: UNP Press

Amir Husin Pangaribuan. 2009. Efektivitas Layanan Bimbingan Kelompok untuk Meningkatkan Pemahaman siswa dalam Menghadapi Ujian (studi eksperimen di MAN Tanjung Morawa Deli Serdang Sumatera Utara). Tesis tidak diterbitkan. Padang : Program Pascasarjana UNP

Dewa Ketut Sukardi. 2003. Pengantar Pelaksanaan Program Bimbingan dan Konseling di Sekolah. Jakarta: Reneka cipta

MunginEdi Wibowo. 2005. Konseling Kelompok Perkembangan. Semarang: UNNES Press

NandangRusmana. 2009. Bimbingan dan Konseling Kelompok di sekolah (metode, tekhnik dan aplikasi). Bandung: Rizki Press

Pascasarjana. 2011. Buku Panduan Penulisan Tesis dan Disertasi. Padang : Program Pascasarjana UNP

Riska Ahmad. 1999. Studi tentang Pengungkapan Hasil Layanan Konseling Perorangan. Tesis. Tidak Dipublikasikan. Padang: UNP.

Prayitno. 1995. Layanan Bimbingan dan Konseling Kelompok (Dasar dan Profil) Jakarta: Ghalia Indonesia

$\begin{array}{ll}\text { Bimbingan dan } & \text { Koyuluhan } \\ \text { Buku Materi Penating: } & \text { Penan } \\ \text { Calon Instruktur BK Di } \\ \text { SMU.Jakarta }\end{array}$

Prayitno dan Erman Amti. 2004. Dasar-Dasar Bimbingan dan Konseling. Cetakan Kedua. Jakarta: PT. Rineka Cipta

Syamsu Yusuf. 2009. Program Bimbingan dan Konseling di Sekolah. Bandung: Rezki Press

Undang-Undang Nomor 20 Tahun 2003. Tentang Sistem Pendidikan Nasional. 